\title{
Drawings and Inscriptions on Pottery Naqada Civilizations and Benefit from them in Enriching the Roofs of Contemporary Ceramic Pots
}

\author{
Eman Ahmad Elsayed Aboelnour \\ Specialist Fine Arts - The Ministry of Culture - Egypt \\ Email: emaan_egypt_2007@yahoo.com
}

Doi:10.5901/mjss.2013.v4n11p250

\begin{abstract}
Naqada civilization dates back to prehistoric times in Egypt. Historians divide that civilization into three historical phases where civilization took Naqada about 1,500 years before the first family.It is a civilization Naqada first (about 4500 to 3500 BC) and the civilization of Naqada II (about 3500 to 3200 BC) and civilization Naqada third (about 3200 to 3000 BC) and was characterized by these civilizations progress pottery and diversity of decorative elements and themes that were recorded on their surfaceswhich express what distract them in their daily lives as a character fishing and agriculture. Fberawa in the use of drawings and engravings bottles decorated pottery drawing humans, animals and plants and geometric shapes .. The research aims to make use of drawings and engravings used by the ancient Egyptians in the civilization of Naqada through the study of personality and semantic expression used by the ancient Egyptians in the use of drawings and engravings and studying different styles of techniques used and bringing it to the entrances experimental variety to enrich the roofs of ceramic pots in a contemporary style for the development of artistic and cultural heritage of the artist.
\end{abstract}

Keywords: Drawings and inscriptions; pottery; Naqada civilizations; contemporary ceramic pots;

\section{Introduction}

Naqada is a town on the west bank of the Nile in the Egyptian governorate of Qena. It was known in Ancient Egypt as Nubt and in classical antiquity as Ombos (pron.: /' $\mathrm{pm}, \mathrm{bDs} /$ ). Its name derives from ancient Egyptian nub, meaning gold, on account of the proximity of gold mines in the Eastern Desert.Naqada comprises some villages such as Tukh, Khatara, Danfiq and Zawayda. It stands near the site of a necropolis from the prehistoric, pre-dynastic period around 4400-3000 BC. Naqada has given its name to the widespread Naqada culture that existed at the time, here, and at other sites including el Badari, Gerzeh and Nekhen (Hierakonopolis). The large quantity of remains from Naqada have enabled the dating of the entire culture, throughout Egypt and environs.The Naqadan culture took over from the Badarian around $4500 \mathrm{BC}$ and became arguably the most important prehistoric culture in Upper Egypt. It is named after the city of Naqada where many of the archaeological evidence for the period was found. The Naqada period was first divided by the British Egyptologist William Flinders Petrie, who explored the site in 1894, into three sub-periods:

Naqada I: Amratian (after the cemetery near El-Amrah).

Naqada II: Gerzean (after the cemetery near Gerzeh).

Naqada III: Semainean (after the cemetery near Es-Semaina).

Petrie's chronology was superseded by that of Werner Kaiser in 1957. Kaiser's chronology began c. 4000 BC, but the modern version begins slightly earlier, as follows:

Naqada I a-b-c (about 4400-3500 BC) black-topped and painted pottery trade with Nubia, Western Desert oases and Eastern Mediterranean(Shaw, Ian (2002.p61). obsidian from Ethiopia(Barbara G. Aston, James A. Harrell, Ian Shaw (2000pp.46-47).

Naqada II a-b-c (about 3500-3200 BC) this culture represented throughout Egypt first marl pottery, and metalworking.

Naqada III a-b-c (about 3200-3000 BC) more elaborate grave goods,cylindrical jars, writing.

\section{Literature review}

This section deals with the definition of civilization Nakada and the importance of the inscriptions and drawing and types of in Nakada civilization on pottery through the theoretical framework and practical experience that shows how to take 
advantage of the inscriptions and drawing in Nakada civilization in enriching the ceramic surface in a contemporary style

\subsection{Definition Nakada}

Naqada is a term used a lot in Predynastic chronology in ancient Egyptian civilization and chronicle about 3400 BC. Naqada is a place located on the west bank of the Nile, around $25 \mathrm{~km}$ north of Luxor and attributed to the village of Naqada in Qena current and found effects in the "Naqada" Albulas - Umrah - Lapidus - Cape, and part of the civilization of Nubia and is divided into two phases, "Naqada initial" age "the proportion of Nag Umrah near Baliana and the second Naqada "civilization جرزة" the proportion of villages Ayat center in Beni Suef current( Nemat Ismail Allam 1988, p 24). Archaeologists began work at Naqada over a century ago; namely Professor Sir W. M. Flinders Petrie and James Quibell of University College London, and Professor John Garstang of Liverpool University. What they found was evidence of an early culture that emerged near the start of the early Predynastic. This culture persisted throughout the predynastic and stretched as far south as Nubia (Hemamein of Naqada I period), and is referred to as Naqadan culture. Naqada III is the last phase of the Naqada culture of ancient Egyptian prehistory, dating approximately from 3200 to 3000 BC (Shaw 2000, p. 479). It is the period during which the process of state formation, which had begun to take place in Naqada II, became highly visible, with named kings heading powerful polities. Naqada III is often referred to as Dynasty 0 or Protodynastic Period (Shaw 2000, p. 479) to reflect the presence of kings at the head of influential states, although, in fact, the kings involved would not have been a part of a dynasty. They would more probably have been completely unrelated and very possibly in competition with each other. Kings' names are inscribed in the form of serekhs on a variety of surfaces including pottery and tombs . Later Kaiser (Kaiser 1957) refined the sequence dates and divided the Naqada period into several Stufen ('steps' = phases).

\subsection{Naqada I a-b-c (about $4000-3500$ BC)}

The other name of this period,is named after the cemetery near El-Amrah. The period is noted is noted for its blacktopped and painted pottery. Black-topped pottery was however more common at badari,and would gradually grow less popular through naqada1.this culture dominated an area from matmar in the north (south of modern minya) and khor bahan (south of aswan) .One interesting characteristic of naqada1, is that war and hunt is represented on ceramics and other objects as dual theme.There are only few and very poor remains of dwellings from this period. Houses are belived to have been built from amixture of mud, wood and reed. The only surviving structure from this period has been found at hierakonpolis.

\subsection{Naqada II a-b-c (about 3500 - 3200 BC)}

This period is named after the grave at Gerzeh which contained 57 richly equipped graves built by mud-brick,It is noted for the first marl pottery, usually with ochre-brown paintintings on beige background.Motifs were either geometrical or representational. The most popular depiction with representational art wew boats. Graves built by mud-brick.It is noted for the first marl pottery,usually with ochre-brown paintings on beige background motifs were either geometrical or representational. The most popular depiction with representational art were boats. The period is also noted for its metalworking,especially with copper.Through naqada 2 copper tools replaced stone tools.Also silver and gold became increasingly used. During naqada2, the macehead changed from disc-shaped to pear-shaped to pear-shaped and also developed into asymbol of power. Throughout pharaonic Egypt it would be the kings weapon. Naqada 2 is a cculture which seems to have spread all across Egypt, apparently by conquest or the establishment of military and trade strongholds.It was during Nqada2 that the techniques of working both soft and hard stones were developed, techniques which would be of central importance during ancient Egyptian civilizations. This culture advanced both south and morth from the area of naqada 1,It reached the eastern edge of the Nile Delta and Nubian Territories, represented by what is referred to as Nubian A Group.In this period, graves become better equipped.Often,multiple burials were used, sheltering up to 5 individuals. The South Town of naqada became the most advanced of Egypt s towns, fortified by walls, and a large mud-brick structure measurhng 30 times 50 metres was built here, possibly a royal palace.

\subsection{Naqada III a-b-c (about $3200-3000$ BC)}

Naqada III is the last phase of the Naqada culture of ancient Egyptian prehistory, dating approximately from 3200 to 
3000 BC (Shaw 2000, p. 479). It is the period during which the process of state formation, which had begun to take place in Naqada II, became highly visible, with named kings heading powerful polities. Naqada III is often referred to as Dynasty 0 or Protodynastic Period (Shaw 2000, p. 479) to reflect the presence of kings at the head of influential states, although, in fact, the kings involved would not have been a part of a dynasty. They would more probably have been completely unrelated and very possibly in competition with each other. Kings' names are inscribed in the form of serekhs on a variety of surfaces including pottery and tombs. The Protodynastic Period in ancient Egypt was characterised by an ongoing process of political unification, culminating in the formation of a single state to begin the Early Dynastic Period. Furthermore, it is during this time that the Egyptian language was first recorded in hieroglyphs. There is also strong archaeological evidence of Egyptian settlements in southern Kanaan during the Protodynastic Period, which are regarded as colonies or trading entrepôts.State formation began during this era and perhaps even earlier. Various small city-states arose along the Nile. Centuries of conquest then reduced Upper Egypt to three major states: Thinis, Naqada, and Nekhen. Sandwiched between Thinis and Nekhen, Naqada was the first to fall. Thinis then conquered Lower Egypt. Nekhen's relationship with Thinis is uncertain, but these two states may have merged peacefully, with the Thinite royal family ruling all of Egypt. The Thinite kings are buried at Abydos in the Umm el-Qa'ab cemetery.

Naqada III extends all over Egypt and is characterized by some sensational firsts:

The first hieroglyphs, The first graphical narratives on palettes, The first regular use of serekhsThe first truly royal cemeteries,Possibly, the first irrigation.

\subsection{Pottery importance Nakada}

Pottery importance as a source in identifying details of the daily life of the people in the ancient times and the manifestation of the progress it through the decoration on pottery can be identified artistic taste of the peoples of the Arabian Peninsula and the extent to which it arrived from the evolution of art. It is through topics decorative, which has Ptniv»a manufacturer on the pottery in the civilization of Naqada can be identified and inferred habit Social and were to play rituals in their daily lives and to identify the kinds of animals, birds and plants that have been used as components decorative and the possibility to identify the quality of use of the Pots and port them fees and inscriptions, both for the purpose of religious or frilly as the decoration on the pottery a prominent role in the identification of indigenous culture and history and the extent of progress and stability.

\section{Research methodology}

\subsection{Theoretical framework}

\subsubsection{Effect of the environment on pottery inscriptions Nakada}

the fact that this can be merely an act of nature spotted by ancient Egyptians and was used as a decorative motif just. This assumption seems to be very reasonable especially that ancient Egyptians were nature lovers, and imitated nature in many scenes and relieves across the Egyptian history. (Lamia elhadede p. 37)

\subsubsection{Vegetable carvings}
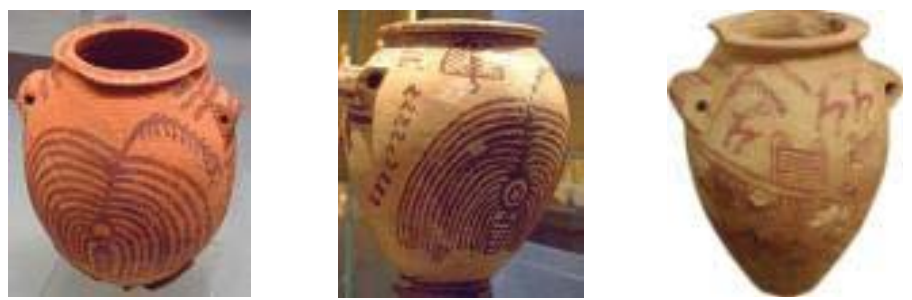

1. Jar depicting plant or tree Naqada II (3650-3300 BCE pottery predynastic Egypt

2. Jar depicting plant or tree Hierakonpolis tomb Naqada II (3650-3300 BCE) predynastic Egypt

3. Petrie Museum. Predynastic (Gerzean) Naqada II. 
We find that a manufacturer in civilization Nakada used forms of plant derived from the environment surrounding it where pictures plants that are deemed especially palm leaves, which were used as a decorative symbolizes the sun and particularly the use of Palm Sunday, which probably looks like the sun (Jawad Ali 1993, p 61.) And there are many of crockeryand fishing boats that carry floral decoration of the environment in the civilization of Naqada. Use the manufacturer in decorating او اونيد pottery in the civilization of Naqada second leaf cactus that had used this element are few and may be due to the preference of other elements such as palm has the code by the Egyptians to stay and immortality to retaining Bkhaddrth for long periods (Ahmed Said 2002, p 47).

\subsubsection{Animal carvings}
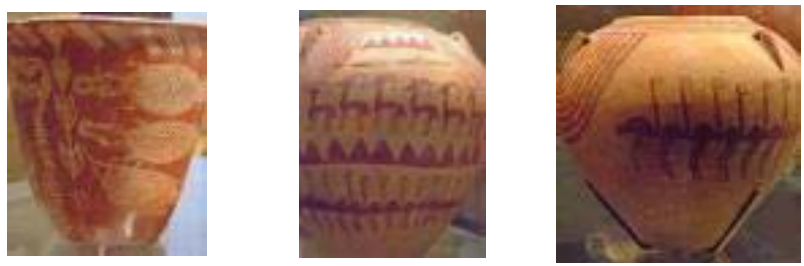

1. Beaker with Nile River Scene Early Naqada II 3650-3500 BCE pottery predynastic Egypt

2. jar with Boat Processions and Animals in Landscape Naqada II (3650-3300 BCE) pottery predynastic Egypt

3. Jar with Flamingos Naqada II (3650-3300 BCE pottery predynastic Egypt

Influenced by the ancient Egyptian in Nakada civilization including surrounded by the environment, animals and birds that appeared in the diversity of animal decorative elements of in Nakada civilization and represented in the crocodile, hippopotamus, giraffe, dog deer, antelope and deer Knew deer, antelope and elk in ancient Egypt since the beginning of the families featured in the inscriptions of cemeteries in wildlife and views the process of hunting and deer meat was delicious meat granulocytes Maher Masri was in the filming of his movement and TINT during the fishing operation and give chase. Photographed some of the animals and reptiles Egyptian environment in ancient Egyptian art and those animals hippo and crocodile reptiles, where they found two examples of pottery and fees which are attributed to Naqada II era and the beginning of the third. In spite of the scarcity of filming the crocodile in the rock carvings, but that it was spread filmed in fees Pottery Naqada initial alone or with a hippo or with a human and then disappeared filmed in the era of Naqada II but re-emerged in the era of Naqada third. (Lamia elhadede 8:00 37). The reverence for some of the animals to normal deals in the order of things Like a snake and frog Kkaúnin Bermaúaan they could live in water and land together, and their ability to Altkaúr and renewal, it has been observed that the snake can change his skin, they think that he was born again and the Frog is Balbaat winter and then come back and multiplies dramatically oversummer and other attributes and features that distinguish each object and sanctified Egyptians these objects since pre-dynastic holy ancient Egyptians these objects and photographed Mabdathm in images of objects Authority pure or body double or vehicle between Okthelr of an object that is, between humans and animals or humans and birds or withsome insects and reptiles (). But they were keen keen to have this installation or blending in terms of acceptable art form. Has appeared evident in the drawings and inscriptions on pottery in Naqada II era.( Abdel Halim Nur al-Din.p.9 ) Ostrich known in Egypt since the pre-dynastic period was from wild animals that received the attention of the ancient Egyptian, where he was taken advantage of down comforters, and appeared ostrich fee decorations and inscriptions on pottery.

\subsubsection{Inscriptions semi Engineering}
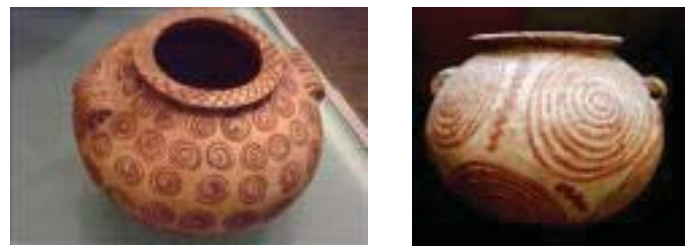

Jar with Small Spirals Early Naqada II (3650-3500 BCE) Pottery Predynastic Egypt 
Use the ancient Egyptian in the civilization of Naqada first inscriptions semi engineering drawing and engraving on the pottery of lines of all kinds either civilization Nakada second was rarely the use of geometric shapes and a high incidence of images natural objects and does not support the artist where a straight line, but was used as the line of corrugated and spiral (Heba Mustafa 1993) and Leary Flandrepettra that the use of the people of Naqada II ancient Egyptian civilization for their use of these lines in Zacharvhm on their vessels pottery may have to use these forms link tenets of religion or perhaps these lines and formations may symbolize the owners or creators of the kind of deities or political situation in their time (Abdel Aziz Saleh, 1987, p 58). these decorations may be due to the impact of the local environment of the artist example corrugated line may suggesting artist Bmgeorh for water.

\subsubsection{Drawing ships}
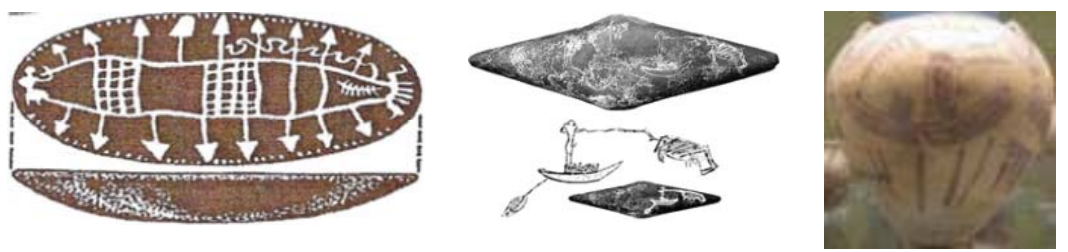

1. Muscat composite horizontal photographer at the bottom of the first dish of Nakada Petrie, F., Prehistoric Egypt , pl.XXIII:2,XV:49

2. The use of a fishing boat in the hippo on the first of Nakada Palette Stockholm Museum

3. Large Jar with Boat Processions and Animals in Landscape Metropolitan Museum of Art

The boats were an essential means of transport products and goods as the Egyptians used to transport the remains of their dead from one bank to another and from one site to another. She also appeared private boats sacred religious ceremonies and rituals at least since the late pre-dynastic period and used boats fishing in the work of both river fishing or hippo. Does not rule out the use of vessels in maritime navigation since Naqada II era. Also found archaeological evidence of the use of boats in the naval battles since the late pre-dynastic period at least. We find as well as images within rock drawings it has become a major theme in charge of these models in the pottery they give us an integrated three-dimensional form to boats during that period(Adams, B. and Cialowicz, K.M 1997, pp. 36 ). Bodies were boats of subjects depicted on pottery white-fees in the first civilization Nakada. Despite the prevalence fees method of intersecting lines in this day and age, people Nakada was characterized accurately observation and dexterity in the filming of the boats. The most photographed boats of this era and curved side only. The images Boats this stage distinctive image of a boat drawn by the author in the development of both sides of the whole, and the image of another boat drawn by the author in Muscat horizontal full as if the artist has drawn as he stood on the beach, drawing parts phenomenon above the water just did not draw its parts missing. And operates a composite image in harmony bottom of the dish . Characterized most of the first boats Nakada their curved surface, and is equal to the forefront with the rear height, and filmed the oars on both sides. At the end of the first era of Nakada boats appeared containing compartment or two above the surface, and the presence of a branch plant or a tree branch probably represent the newspaper in the forefront of that palm something about rose hips(salh .p136. Photos of boats on the second Pottery Nakada popularized photography boats on the second Pottery Nakada a red fees. It was not a picture boat on pottery one of the topics pictures only, but the image is the central and main pottery, and it is around distributed the rest of the images Adamic, animal and plant engineering and other decorative elements other form - perhaps indicating frequent filming boats on they started to play a major role in the lives of Egyptians, as evidenced by the increasing need of the Egyptians since that period, in addition to the frequent use of them. Maintained boats Nakada second characteristics old appeared in Nakada first, including filming two compartment for each compound was probably from the stems of the jungle and plants Scheduled (Badawy, A.p4 )This was chapels either with a flat roof or a semi-circular, and highlights it sometimes parties sticks woven palm leaves used in their construction. Often separates the Almqsourtin the corridor and sometimes no connection between them from the top. Perhaps these cabins allocated for boat owners or VIP in public boats, and the precious cargo in transport boats and boats retained second Nakada also the existence of a plant or tree branch in the prow, which appeared in the pictures of boats since the first Nakada endings. Some felt that they represent long sift newspaper was probably shade composite navigator who was sitting underneath, plus they give a share of the decorations on their boats. Appeared pottery in the civilization of Naqada bear ornament on the ship, has spread these decoration on pottery pre-dynastic 
ancient Egyptian civilization draw ships on pottery and lines of corrugated represent water (Salim Hassan 2001, pp. 85.86) and the pottery of the era Nakada Central Charges boats and provided each Bakmrat on Stah»a, and still intended to obscure and probably accounted for ships funeral to cross the Nile and the drawings of palm fronds, and topped صاريات probably represent the symbols of deities Egyptian may be referring to the city or the port to which it belongs (Jaroslav Cherni 1951, p 7). Some see in this branch plant evidence on the use of sail boats in Egypt since the pre-dynastic period( Basch 1987, p.49), .And that you make sure to appear in some photos of the boats at the end of this era and clearly on the mat is installed on a vertical column (Landström, B. 1970, p. 133,) and appeared Property) newspaper sieving (in most boats, but became more abstract and less consistent and widespread before the start of the first family. (Raban, A.,p.377) and hanging from the front of some boats what looks like a rope (Bowen, R.p120) or a tool that works on the cleaning and the removal of what may object houseboats time sailing.

\subsubsection{Drawing human}
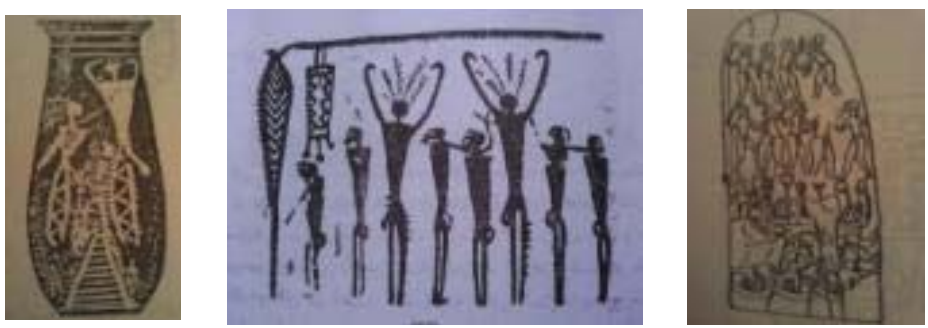

Pots and Pottery by drawing human naqada 1

That the types of pottery decoration industries to provide evidence of the ability of human creations since ancient times in all the clarity of what is described as aesthetic value, and gives it a kind of self-satisfaction has adopted the decoration on pottery at the beginning of the simplicity and abstraction in the elements(Sixty Lloyd1988,p29) He has appeared in Nakada 1 Pots Pottery by drawing humanity marked by simplicity and abstraction

\subsection{Practical framework:}

Was used with some drawing and engraving on pottery civilization Nakada was redrafted and strip it in configurations innovative through some processors technical which produced about it some designs that lend themselves for use in enriching the surfaces of ceramic and we note clarify the the idea of search using different techniques to suit the nature of these designs ,such as prominent relief techniques, vaccination, textures, coloring lining, abrasive style in the lining.

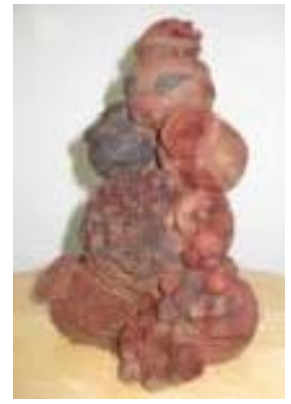

Form (1)

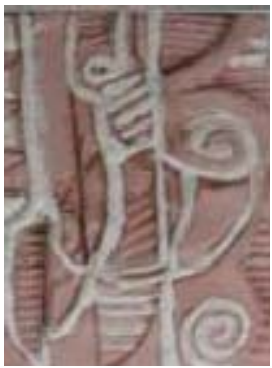

Form (2)

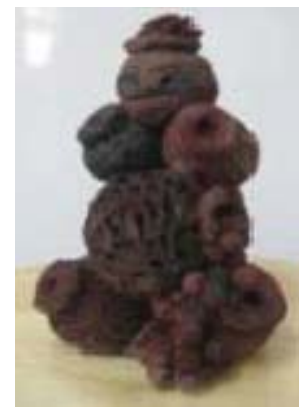

Form (3) 


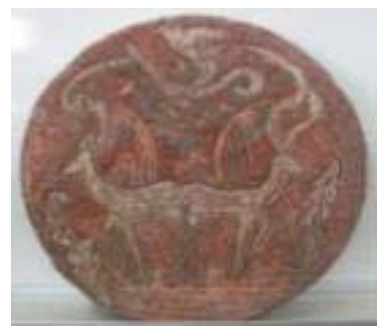

Form (4)

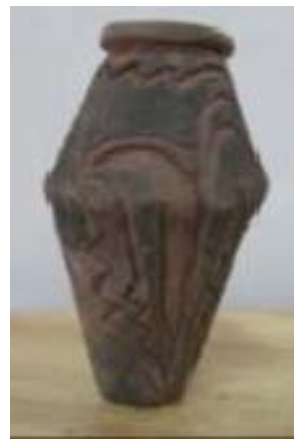

Form (7)

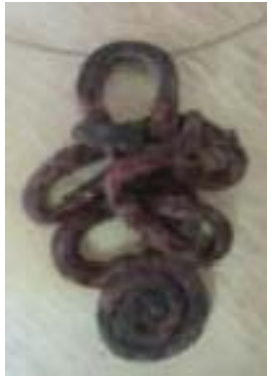

Form (5)

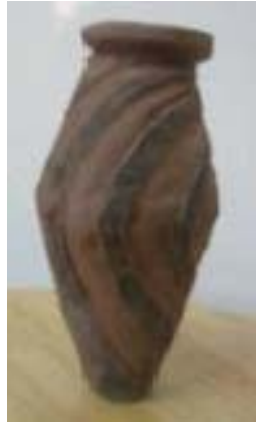

Form (8)

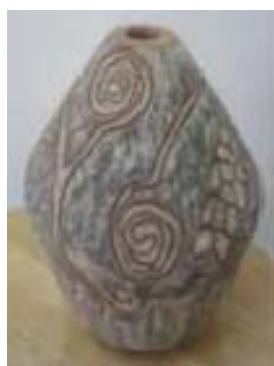

Form (6)

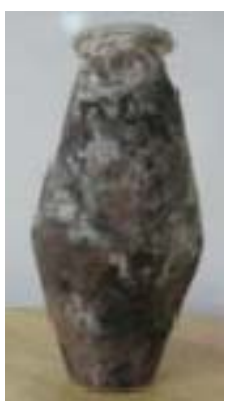

Form (9)

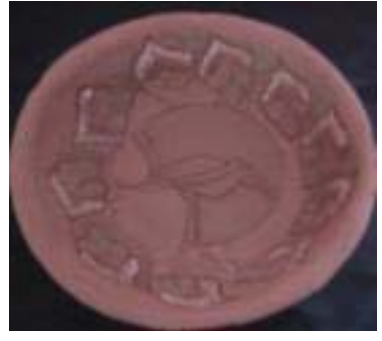

Form (10)

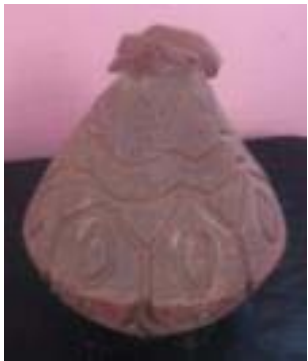

Form (11)

\section{Findings and discussion}

1. man knew pottery since an old eras and making tools and crockery for each community was his nature and his character about this industry

2. care manufacturer to the external surface of the vase and fill pores before the fire and colored after fire

3. The artist plays an important role in the process of decoration to beautify surfaces, crockery, pots appeared the influence of the environment used decorative elements from nature

4. Artist benefited a lot from animals and birds widespread of Environment in the region and used as decoration elements such as crocodile, ostrich, deer and seahorses

5. The possibility take advantage of the inscriptions and painting on Naqada pottery in enrich contemporary ceramic surfaces

6. Selection can of heritage revival of what is worthwhile intellectual and mental contents can be applied in practice, and adds the new roads developed to enrich the ceramic surfaces.

7. Detection methods and creative ways of thinking, as a connection and communication between all of the artistic heritage of ancient and contemporary artistic life. 


\section{Concluding remarks}

Not stand the role of the artist in dealing with heritage at the borders of Transportation or the interpretation or classification, but went beyond that to understand how to employ them and the possibility of investing in addressing some of the contemporary problems and look at her perspective a special link between scientific knowledge in heritage and process associated with new technologies a manner confirms the Authenticity and Modernity and detectedmethods and innovative ways of thinking as a connection and communication between all of the artistic heritage of ancient and contemporary artistic life and a choice of what heritage is is worthwhile intellectual and mental contents can be applied in practice, and adds the new methods developed to enrich the ceramic surfaces

\section{References}

Abdel Halim Nur al-Din: Mohab setting Darwish: terrestrial and aquatic animals in ancient Egypt, the Library of Alexandria Abdul Aziz Saleh: Ancient Near East "Egypt and Iraq," the first part, fourth edition, 1987 Cairo,

Adams, B. and Cialowicz, K.M., Protodynastic Egypt, Buckinghamshire, 1997

Ahmad Said: "crockery in pre-history in the ancient Near East comparative study in the industry and decoration" Studies on the effects of the Arab world 3, the Fifth Conference of Arab Archaeologists Association, Cairo, 2002.

Barbara G. Aston, James A. Harrell, Ian Shaw (2000). Paul T. Nicholson and lan Shaw editors. "Stone," in Ancient Egyptian Materials and Technology, Cambridge, 5-77, pp. 46-47. Also note: Barbara G. Aston (1994). "Ancient Egyptian Stone Vessels," Studien zur Archäologie und Geschichte Altägyptens 5, Heidelberg

Barbara G. Aston (1994). "Ancient Egyptian vessels Stone," Studien zur Archäologie und Geschichte Altägyptens, of Heidelberg,

Bataille, Rafael (1998),"Children of Noah: Jewish sailor in ancient times"(Princeton Uni Press)

Basch, L., Le musée imaginaire de la marine antique, Athensm, 1987

Bowen, R., «Egypt,s earliest sailing ships», Antiquity 34, 1960, p. 120, fig..

Childe, V. Gordon (1953), "New light on the most ancient Near East" (Praeger Publications

Emberling, Jeff (2011) Nubia: Ancient Kingdoms of Africa. New York: Institute for the study of the ancient world.

"Faience in different periods." Digital Egypt for Universities, University College London. 2008.

Ikram, intact. Choice cuts: meat production in ancient Egypt. University of Cambridge.1992

Nemat Ismail Allam: Art ancient Middle East, the fifth edition, Cairo, 1988,

Jawad: detailed in the history of the Arabs before Islam, Part VII, Baghdad, 1993

Jaroslav Cherni: ancient Egyptian religion, translated by Ahmed Qadri, Mahmoud Maher Taha Review, London, 1951

Lamia Ali Shawki elhadede : views of hippo and crocodile in rock carvings and pottery fees in the prehistoric era in Egypt, studies on the effects of the Arab world (2), the Faculty of Archaeology, Cairo University

Landström, B., Ships of the Pharaons, London, 1970;; Wachsmann, S., Seagoin

Raban, A., The Enigma of the long planks Predynastic Boats on the Upper Nile,Tropis IV.

Shaw, Ian, ed. (2000). The Oxford History of Ancient Egypt. Oxford University Press.

Ikram Salima: Choice Cuts: Meat Production in Ancient Egypt, University of Cambridge1992,

Sixty Lloyd: The Art of the Ancient Near East, translated by Mohammad Darwish, Baghdad, 1988, p 29.

http://www.nemo.nu/ibisportal/0egyptintro/2aegypt/index.htm

http://web.me.com/kbolman/Egypt_3,000_BCE/Pottery_from

http://www.digitalegypt.ucl.ac.uk/naqadan/painting.html

http://www.metmuseum.org/toah/works-of-art/20.2.10 